\title{
HALOTHANE-INDUCED HYPOTENSION AND THE EFFECT OF VASOPRESSORS
}

\author{
Robert W. Loehning, M.D., PH.D., ${ }^{1}$ and Vasil, P. Czorny, M.D. ${ }^{2}$
}

EPINEPHRINE, norepinephrine, ephedrine, and desoxyephedrine have been reported to have initiated ventricular arrhythmias in dogs anaesthetized with halothane (1). On the other hand, no irregularities other than bradycardia were found under similar conditions with methoxamine and phenylephrine $(1,2)$. Cardiac irregularities occuring with epinephrine and norepinephrine administrations in patients under halothane anaesthesia are well documented (3-5). Brindle et al. (4) reported safely using methoxamine and phenylephrine infusion for hypotension during halothane administration. Other authors have reported $(5,6)$ successfully administering methoxamine for sudden achte hypotension during halothane anaesthesia. Wyant and his co-workers ( 7 ) gave doses of $2.5 \mathrm{mg}$. of phenylephrine intravenously to hypotensive subjects receiving halothane and found premature ventricular contractions in two of four patients.

This study was undertaken to determine the effects of methoxamine, phenylephrine, and mephentermine given intravenously during extreme hypotension induced by halothane.

\section{MethoD}

Seventy studies on 48 mongrel dogs weighing from 8 to $20 \mathrm{~kg}$. were analysed for this series. Dogs that were used for a second study had a three-day rest between experiments. The animals were given sufficient thiopental to allow endotracheal intubation and vessel canulations. The animals were respired throughout the experiment with a volume-limited ventilator (Palmendeal Pump) with a 30 per cent oxygen and a 70 per cent nitrogen mixture. Tidal volumes were adjusted to maintain end-tidal carbon dicxide tensions of $35-40 \mathrm{~mm}$. of mercury at the beginning of each experiment. The dogs were allowed to awaken after the induction dose of thiopental before halothane was started. Halothane vaporized with a "bubble through vaporizer" was given in a semi-closed system with carbon dioxide absorption in concentrations necessary to lower the intraaortic pressure to $20-40 \mathrm{~mm}$. of mercury within a 3-5 min. period. When the desired hypotension was achieved, the anaesthetic was discontinued and the ventilator adjusted to deliver twice the pre-existing tidal volume. Eight of the dogs in the series were not given vasopressors and are designated as controls. All other animals received vasopressors when the blood pressure decreased to the desired hypotensive level. Vasopressors were diluted with saline and $1 \mathrm{ml}$. of this dilution was given every $30 \mathrm{sec}$. until a pressor response was initiated after which it was discontinued (phenylephrine $.5 \mathrm{mg} . / \mathrm{ml}$., mephentermine $5 \mathrm{mg} . / \mathrm{ml}$.;

${ }^{1}$ Assistant Professor, Division of Anesthesiology, University of Utah.

${ }^{2}$ Resident in Anesthesiology, Division of Anesthesiology, University of Utah.

304

Can. Anaes. Soc. J., vol. 7, no. 3, July, 1960. 
methoxamine $2 \mathrm{mg} . / \mathrm{ml}$.). Cardiac rhythm was recorded with a Sanborn electrocardiograph (lead II) and blood pressure measured with a mercury manometer through an intra-aortic catheter.

\section{RESULTS}

Seven of the eight dogs serving as controls who were rendered hypotensive with halothane and hyperventilated after discontinuance of the anaesthetic returned to "normal" blood pressures within a $10 \mathrm{~min}$. period. The remaining animal developed cardiac standstill. Most of the animals under halothane exhibited ECG changes of depression or inversion of $T$ waves and bradycardia. No significant cardiac arrhythmias occurred as the blood pressure fell or as it returned toward normal.

A high incidence of cardiac irregularities including ventricular fibrillation followed the administration of vasopressors. In Table I are presented the irregularities seen both in the controls and in those receiving vasopressors. Each animal studied is listed only once and is listed under the most severe arrhythmia noted. Many animals developed more than one type of arrhythmia, often having progressive patterns of ventricular extrasystoles, multifocal ventricular rhythm, paroxsymal ventricular tachycardia, and ventricular tachycardia. Atrioventricular block occurred in four out of twelve animals receiving methoxamine. Total doses of vasopressor given before a rise in blood pressure was initiated showed wide variations: methoxamine $2-12 \mathrm{mg}$.; phenylephrine $0.5-5 \mathrm{mg}$.; and mephentermine 5-45 mg. No correlation could be found when the dose of drug on a mg. $/ \mathrm{kg}$. basis was compared with severity of irregularities (Fig. 1). When the data were subjected to the chi-square test, no significant differences were found between the incidence of irregularities between the groups receiving phenylephrine, methoxamine, or mephentermine.

To determine if hyperventilation following hypotension influenced the incidence of irregularities with vasopressor administration, eight dogs were picked at random during the course of the study and were maintained at control tidal volumes. There appeared to be no difference in the incidence or severity of the irregularities between those animals treated in the above manner and the other animals receiving vasopressors in the study.

Twenty-two dogs were given atropine $1 \mathrm{mg} . / \mathrm{kg}$. intravenously and after $15 \mathrm{~min}$. were subjected to halothane anaesthesia to the point of hypotension and then given vasopressor therapy. While the incidence of irregularities was unchanged, none of the animals pretreated with atropine developed ventricular fibrillation (see Table I). This finding, however, namely the reduction in ventricular fibrillation in the dogs receiving atropine when compared with those not receiving atropine, was not found to be significant when the data were subjected to the chi-square-test $p<.250$.

None of the dogs who had a pressor response following the catechol amines exhibited arrhythmias until the mean blood pressure reached $100 \mathrm{~mm}$. of mercury, the average of 43 dogs was $140 \mathrm{~mm}$. of mercury with a range of 100 to $220 \mathrm{~mm}$. of mercury. Attempts to titrate vasopressors to prevent rises over pre-existing blood pressures were largely unsuccessful. Two dogs did not develop hypertension 


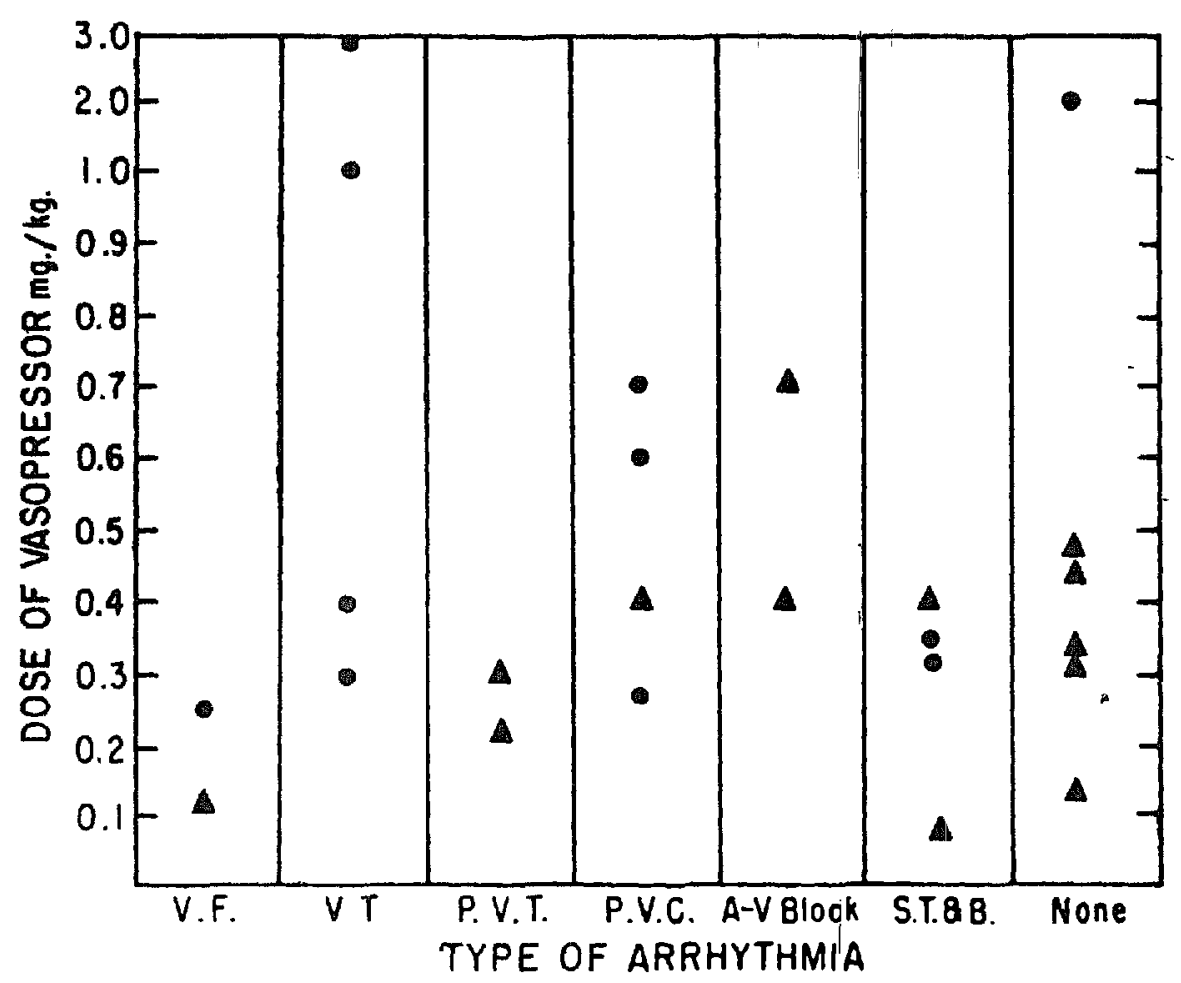

FIGURE 1. Variations in dosage of vasopressor necessary to correct hypotension and the most severe irregularity occurring with the doses of methoxamine and mephentermine used.

V.F., ventricular fibrillation; V.T., ventricular tachycardia; P.V.T., paroxysmal ventricular tachycardia; P.V.C., premature ventricular contractions; S.T. \& B., sinus tachycardia and bradycardia; closed circle, mephentermine; closed triangle, methoxamine.

and also did not have arrhythmias. However, upon administration of additional vasopressors, hypertension and irregularities were initiated.

Eight dogs (not included in Table I) having cardiac arrhythmias following vasopressor therapy for halothane-induced hypotension were treated withintravenous trimethaphan camphorosulfonate (Arfonad). Concomitant with a fall in blood pressure from the hypertensive state cardiacl irregularities ceased and the ECG pattern returned to normal sinus rhythm.

\section{Comment}

No attempt was made to determine the cause of the cardiac arrhythmias and we cannot conclude from results of this study that halothane per se "sensitized" the myocardium to the catechol amines. Other factors which may have influenced development of irregularities were: (i) hypotension during the halothane administration with presumably some degree of tissue hypoxia and hypercarbia: (ii) hypertension following administration of vasopressor. Lurie and co-workers (8) found that hypercarbia induced cardiac irregularities in subjects anaesthetized with cyclopropane. Indeed, the authors have observed arrhythmias in some dogs under barbiturate anaesthesia with each of the sympathomimetic amines used in this study but only when hypertension was produced. Stutzman et al. giving 
TABLE I

InCIDENCE OF ARRhythMia FOLLOWING VASOPREsSOR AdMinistration DURING HyPotension INDUCED BY HALOTHANE*

\begin{tabular}{|c|c|c|c|c|c|c|c|}
\hline Type of arrhythmia & $\begin{array}{c}\text { No } \\
\text { vasopressor }\end{array}$ & & $\begin{array}{c}\text { Phenylephrine } \\
\text { Atropine } \\
(1 \mathrm{mg} . / \mathrm{kg} .)\end{array}$ & & $\begin{array}{c}\text { Mephentermine } \\
\text { Atropine } \\
\text { (1 mg. } / \mathrm{kg} .)\end{array}$ & & $\begin{array}{l}\text { Methoxamine } \\
\text { Atropine } \\
\text { (1 mg./kg.) }\end{array}$ \\
\hline $\begin{array}{l}\text { Ventricular fibrillation (hypo- } \\
\text { tensive) }\end{array}$ & & 2 & & & & 1 & \\
\hline $\begin{array}{l}\text { Ventricular fibrillation (hyper- } \\
\text { tensive) }\end{array}$ & & 2 & ${ }_{1}^{\left(.1 m^{\prime}\right.}$ & 1 & & 1 & \\
\hline $\begin{array}{l}\text { Cardiac standstill } \\
\text { Ventricular tachycardia }\end{array}$ & 1 & $\begin{array}{l}2 \\
4\end{array}$ & 4 & 2 & 2 & & \\
\hline $\begin{array}{l}\text { Paroxysmal ventricular } \\
\text { tachycardia }\end{array}$ & & & 1 & & & & 2 \\
\hline $\begin{array}{l}\text { Premature ventricular con- } \\
\text { tractions }\end{array}$ & & 1 & & & & & \\
\hline $\begin{array}{l}\text { Multifocal venticular } \\
\text { rhythm }\end{array}$ & & & & 1 & & 1 & 1 \\
\hline $\begin{array}{l}\text { Bigeminal rhythm } \\
\text { Occasional extrasystoles }\end{array}$ & & & 2 & 1 & 3 & & \\
\hline Atrioventricular block & & 1 & & 1 & & 4 & \\
\hline $\begin{array}{l}\text { Sinus arrhythmia } \\
\text { Sinus bradycardia }\end{array}$ & & 1 & & 1 & & 5 & \\
\hline No arrhythmias & 7 & $\mathbb{1}$ & 2 & 1 & & 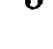 & 2 \\
\hline Ventricular arrhythmias (\%) & 12 & 92 & $8 \overline{1}$ & $7 \overline{5}$ & 100 & 58 & 60 \\
\hline
\end{tabular}

*Each dog is listed under the most severe irregularity which occurred.

unanaesthetized dogs $1 \mathrm{mg} . / \mathrm{kg}$. of methoxamine found a 30 per cent incidence of atrioventricular block (9). Brofman and co-workers (10) state that mephentermine in "unusually large doses" causes premature ventricular contractions in dogs under pentobarbital anaesthesia. The association of cardiac irregularities with hypertension following sympathomimetic amines has also been described by others. Raventos (2) using dogs'anaesthetized with halothane concluded that ventricular arrhythmias had a relationship to elevation of blood pressure because equipressor doses of norepinephrine and epinephrine were equally active in producing arrhythmias. On the other hand, he states that mephentermine and methoxamine produce rises in blood pressure comparable to those with epinephrine without inducing arrhythmias. Moe et al. (11) using dogs anaesthetized with cyclopropane found that when a rise in blood pressure after epinephrine was prevented by means of a "pressor regulator" the incidence of irregularities diminished and the animals could tolerate higher doses of epinephrine before arrhythmias occurred. Cummings and Hays (12), on the other hand, could find no definite correlation between the capacity of adrenergic drugs to elevate blood pressure and induce cardiac irregularities in dogs under cyclopropane anaesthesia. Furthermore, the above authors state that isopropylnorepinephrine (Isuprel) induces cardiac arrhythmias during hypotension produced by the drug. Ventricular fibrillation following administration of phenylephrine, methoxamine, or mephentermine to our knowledge has not been reported by others nor has it been observed by us in unanaesthetized dogs or those under barbiturate anaesthesia.

Nickerson et al. (13) found that atropine in large doses $1 \mathrm{mg} . / \mathrm{kg}$. gave partial 
protection to dogs against epinephrine-induced arrhythmias with cyclopropane. It was concluded that atropine had its major protective action by some direct effect on the myocardium. Levy (14) reached a similar conclusion using/chloroform anaesthesia. It should be emphasized, however, that the dose of atropine used in the above studies and in this present study is 50 to 100 times as great on a weight basis as that usually employed clinically to produce parasympathetic blockade.

We have not as yet determined the cause for the cessation of arrhythmias after trimethaphan camphorosulfonate administration. Possible explanations are that it may be the result of a peripheral action of the drug reducing blood pressure, a direct myocardial action, or of ganglionic blockade.

\section{SUMMARY}

Seven of eight dogs on fixed-volume ventilation and subjected to concentrations of halothane which lowered blood pressure to $20-40 \mathrm{~mm}$. of mercury recovered when the anaesthetic was discontinued and hyperventilation was instituted. None of the dogs developed arrhythmias while hypotension was being induced or as its blood pressure returned to pre-existing levels. The remaining animal developed cardiac standstill.

Phenylephrine, methoxamine, and mephentermine administration during hypotension was followed by a high incidence of cardiac irregularities.

Pretreatment of dogs with $1 \mathrm{mg} . / \mathrm{kg}$. of atropine did not prevent arrhythmias.

Trimethaphan camphorosulfonate (Arfonad) given at the time irregularities occurred produced a fall in blood pressure with a concomitant conversion of the ECG pattern to normal sinus rhythm.

\section{ACKNOWLEDGMENTS}

We wish to thank Dr. George Carman of the Division of Cardiovascular Medicine of the University of Utah for his assistance with electrocardiograph interpretations.

\section{RÉSUMÉ}

Sur huit chiens dont la ventilation était maintenue à un volume fixe et qui étaient soumis à des concentrations d'halothane suffisantes pour abaisser leur tension artérielle de 20 à $40 \mathrm{~mm}$. de $\mathrm{Hg}$, sept ont récupéré à la cessation de l'anesthésie et à l'installation d'une hyperventilation. Aucun des animaux n'a présenté d'arythmie au cours de l'hypotension pas plus qu'au retour de la pression à la normale. Le huitième chien a présenté un arrêt cardiaque en diastole. Au cours de l'hypotension, l'injection de phenylephrine, de methoxamine et de mephentermine a entraîné de très fréquentes irrégularités cardiaques. Le traitement préventif de ces arythmies en injectant $1 \mathrm{mg} . / \mathrm{kg}$. d'atropine n'a pas été efficace. Injecté au moment de l'apparition des irrégularités, le trimethaphan camphorosulfonate (Arfonad) a provoqué une chute de pression et une modification concomittante du tracé électrocardiographique en un rythme sinusal normal. 


\section{REFERENCES}

1. Stephen, C. R.; Margolis, G.; Fabian, L. W.; \& Bourgeors-Gavardin, M. Laboratory Observations with Fluothane. Anesthesiology 19: 770 (1958).

2. Raventos, J. The Action of Fluothane-a New Volatile Anaesthetic. Pharm. \& Chem. 11: 394 (1956).

3. Chang, J., MacCartney, H. M., \& Graves, H. B. Clinical Experiences with Fluothane: A New Non-explosive Anaesthetic Agent. Canad. Anaesth. Soc. J. 4: 187 (1957).

4. Brindle, G. F., Grlbert, R. G. B., \& Millar, R. A. The Use of Fluothane in Anaesthesia for Neurosurgery: A Preliminary Report. Canad. Anaesth. Soc. J. 4: 265 (1957).

5. Virtue, R. W.; Payne, K. W.; Caranna, L. J.; Gordon, G. S.; \& Rember, R. R. Observations during Experimental and Clinical Use of Fluothane. Anesthesiology 19: 478 (1957).

6. Johnstone, M. The Human Cardiovascular Response to Fluothane Anaesthesia. Brit. J. Anaesth. 28: 392 (1956).

7. Wyant, G. M.; Merriman, J. E.; Kilduff, C. J.; \& Thomas, E. T. The Cardiovascular Effects of Halothane. Canad. Anaesth. Soc. J. 5: 384 (1958).

8. Lurie, A. A.; Jones, R. E.; Linde, H. W.; Price, M. L.; Dripps, R. D.; \& Price, H. L. Cyclopropane Anesthesia. I. Cardiac Rate and Rhythm during Steady Levels of Cyclopropane Anesthesia at Normal and Elevated End-expiratory Carbon Dioxide Tensions. Anesthesiology 19:457-(1958).

9. Stutzman, J. W., Petringa, F. L., \& Fruggiera, E. J. Cardiac Effects of Methoxamine and Desoxyephedrine during Cyclopropane Anesthesia. J. Pharmacol. \& Exper. Therap. 97: 385 (1949).

10. Brofman, B. L., Hellerstein, H. K., \& Caskey, W. K. Mephentermine-An Effective Pressor Amine. Am. Heart J. 44: 396 (1952).

11. Moe, G. K.; Malton, S. D.; Rennick, B. R.; \& Freyburger, W. A. The Role of Atrial Pressure in Induction of Idioventricular Rhythms under Cyclopropane Anesthesia. J. Pharmacol. \& Exper. Therap. 94: 319 (1948).

12. Cummings, J. R., \& Hays, H. W. Cardiovascular Studies of Adrenergic and Ganglionic Stimulating Drugs Administered during Cyclopropane. Anesthesiology 17: 314 (1956).

13. Nickerson, M., Toman, J. E. P., \& Hecht, H. H. Effect of Atropine on Epinephrine Induced Cardiac Irregularities. Federation Proc. 6: 361 (1947).

14. Levy, A. C. The Exciting Causes of Ventricular Fibrillation in Animals under Chloroform Anesthesia. Heart 4: 319 (1913). 